NBER WORKING PAPER SERIES

\title{
WHAT MEASURE OF INFLATION SHOULD A DEVELOPING COUNTRY CENTRAL BANK TARGET?
}

\author{
Rahul Anand \\ Eswar Prasad \\ Boyang Zhang \\ Working Paper 21388 \\ http://www.nber.org/papers/w21388 \\ NATIONAL BUREAU OF ECONOMIC RESEARCH \\ 1050 Massachusetts Avenue \\ Cambridge, MA 02138 \\ July 2015
}

We are grateful to the editor, Ricardo Reis, and an anonymous referee for their detailed and constructive comments. We also thank Kaushik Basu, Gita Gopinath, Karel Mertens, Parul Sharma, Viktor Tsyrennikov, and Magnus Saxegaard for helpful comments and discussions. We received helpful comments from seminar participants at the Bank of Korea, the Brookings Institution, Cornell University, the Federal Reserve Board, the IMF, and the Reserve Bank of India. We thank James Walsh for sharing some of his data with us. This research was supported by a grant from the International Growth Centre's Macroeconomics Program. The views expressed herein are those of the authors and do not necessarily reflect the views of the National Bureau of Economic Research.

NBER working papers are circulated for discussion and comment purposes. They have not been peerreviewed or been subject to the review by the NBER Board of Directors that accompanies official NBER publications.

(C) 2015 by Rahul Anand, Eswar Prasad, and Boyang Zhang. All rights reserved. Short sections of text, not to exceed two paragraphs, may be quoted without explicit permission provided that full credit, including $($ notice, is given to the source. 
What Measure of Inflation Should a Developing Country Central Bank Target?

Rahul Anand, Eswar Prasad, and Boyang Zhang

NBER Working Paper No. 21388

July 2015

JEL No. E31,E52,E61

\begin{abstract}
$\underline{\text { ABSTRACT }}$
In closed or open economy models with complete markets, targeting core inflation enables monetary policy to maximize welfare by replicating the flexible price equilibrium. We analyze this result in the context of developing economies, where a large proportion of households are credit constrained and the share of food expenditures in total consumption expenditures is high. We develop an open economy model with incomplete financial markets to show that headline inflation targeting improves welfare outcomes. We also compute the optimal price index, which includes a positive weight on food prices but, unlike headline inflation, assigns zero weight to import prices.
\end{abstract}

Rahul Anand

International Monetary Fund

Institute for Capacity Development

700 19th Street, N.W.

Washington, DC 20431

ranand@imf.org

Eswar Prasad

Dyson School of Applied Economics and

Management

Cornell University

301A Warren Hall

Ithaca, NY 14853

and NBER

eswar.prasad@cornell.edu
Boyang Zhang

Department of Economics

Cornell University

Ithaca, NY, 14853

bz95@cornell.edu 


\section{Introduction}

Most central banks view low and stable inflation as a primary, if not dominant, objective of monetary policy. In the existing literature, the choice of price index to target has been guided by the idea that inflation is a monetary phenomenon. Core inflation (excluding food, energy, and other volatile components from headline CPI) has been viewed as the most appropriate measure of inflation since fluctuations in food and energy prices represent supply shocks and are non-monetary in nature (Wynne, 2008). Moreover, since these shocks are transitory, highly volatile, and do not reflect changes in the underlying rate of inflation, they should not be a part of the targeted price index (Mishkin, 2007, 2008).

Previous authors have used models with price and/or wage stickiness to show that targeting core inflation maximizes welfare. Existing models have looked at complete market settings where price stickiness is the only distortion (besides monopoly power). Infrequent price adjustments cause mark-ups to fluctuate and also distort relative prices. In order to restore the flexible price equilibrium, central banks should try to minimize these fluctuations by targeting sticky prices (Goodfriend and King, 1997, 2001).

Using a New Keynesian model, Aoki (2001) demonstrates that targeting inflation in the sticky price sector leads to macroeconomic stability and welfare maximization. Targeting core inflation is equivalent to stabilizing the aggregate output gap as output and inflation move in the same direction under complete markets. Benigno (2004) argues that in a common currency area the central bank should target an index that gives higher weight to inflation in regions with a higher degree of nominal rigidity, effectively ignoring exchange rate and commodity price fluctuations. In a more general multi-sector setting, Mankiw and Reis (2003) show that, in order to improve the stability of economic activity, the targeted "stability" price index should put more weight on sectors that have sluggish price adjustment, are more procyclical, and have a smaller weight in the consumer price index.

The results from the prior literature generally rely on the assumption that markets are 
complete (allowing households to fully insure against idiosyncratic risks). The central bank then only needs to tackle the distortions created by price stickiness. However, in developing economies, a substantial fraction of agents are unable to smooth their consumption in a manner consistent with the permanent income hypothesis. Moreover, developing economies have other structural differences from advanced economies, including the relatively high share of food in household consumption expenditures.

In this paper, we provide an analytical framework for determining the optimal price index for developing economy central banks to target. We make three main contributions. First, we generalize the results of Aoki (2001) and Benigno (2004) by developing a model that encompasses their frameworks. Second, we show that incomplete financial markets and other characteristics of developing economies substantially alter the key results. Third, we derive optimal price indexes and compare them with feasible rules such as headline inflation targeting that also improve welfare relative to core inflation targeting but are easier for central banks to communicate and implement.

Our model has three sectors to make it more representative of the structures of developing economies. First, the food (or informal) sector, which comprises a large fraction of the economy and where prices are flexible. Workers in this sector live hand-to-mouth, i.e., they have no access to credit markets and simply consume their current labor income. Second, the sticky price (or formal) sector that is subject to productivity shocks and mark-up shocks, and where workers do have access to credit markets. Third, a sector that is open to foreign trade and where prices are flexible but also highly volatile. This sector, which proxies for the commodity-producing sector, faces large external shocks.

Financial frictions that result in consumers being credit constrained have not received much attention in models of inflation targeting. When markets are not complete and agents differ in their ability to smooth consumption, their welfare depends on the nature of idiosyncratic shocks. Thus, this model also allows us to analyze the welfare distribution under 
alternative inflation targeting rules. Under incomplete markets, household income, which is influenced by the nature of shocks and the price elasticity of the demand for goods, matters for consumption choices. For instance, a negative productivity shock to a good with a low price elasticity of demand could increase the income of net sellers of that good and raise the expenditure of net buyers of that good.

Our model incorporates other important features relevant to developing economies. In these countries, expenditure on food constitutes 40-50 percent of household expenditures, compared to 10-15 percent in advanced economies. Low price and income elasticities of food expenditures as well as low income levels make the welfare of agents in developing economies more sensitive to fluctuations in food prices. These features imply that agents factor in food price inflation while bargaining over wages, thus affecting broader inflation expectations (Walsh, 2011). Thus, in developing economies even inflation expectation targeting central banks must take into account food price inflation.

Our key result is that in the presence of financial frictions targeting headline CPI inflation improves aggregate welfare relative to targeting core inflation (i.e., inflation in the sticky price sector). Lack of access to financial markets makes the demand of credit-constrained consumers insensitive to interest rates. These consumers' demand depends only on real wages, establishing a link between aggregate demand and real wages. Thus, the relative price of the good produced in the flexible price sector not only affects aggregate supply but, through its effects on real wages, also influences aggregate demand.

Our model allows us to compute optimal price indexes that maximize welfare. The optimal price index also includes a positive weight on food prices but, unlike headline inflation, generally assigns zero weight to import prices. This is because agents in that sector have access to financial markets and, unlike in the case of food, the price elasticity of the demand for goods produced in this sector is high.

These results differ from those of the prior literature based on complete markets settings. 
For instance, in Aoki's (2001) model, relative prices of the flexible price sector only appear as a shift parameter of inflation in the sticky price sector. Under incomplete markets, by contrast, the central bank has to respond to price fluctuations in the flexible price sector in order to manage aggregate demand. Financial frictions break the comovement of inflation and output, implying that stabilizing core inflation no longer stabilizes the output gap. Thus, in the presence of financial frictions, targeting a broader measure of inflation improves welfare.

In related work, Catão and Chang (2010) show that, for a small open economy that is a net buyer of food, the high volatility of world food prices causes headline CPI inflation targeting to dominate core CPI inflation targeting. Adding this feature would strengthen our results but make our model less general since few developing economies import a large share of their food consumption. Frankel (2008) argues that a small commodity-exporting economy should target the export price index in order to accommodate terms of trade shocks. Our results suggest that ignoring sectors with nominal rigidities and targeting this set of flexible prices, which has a small weight in the domestic CPI, would reduce welfare.

The paper is organized as follows. The next section contains some empirical facts to further motivate the structure of the model and its relevance to developing economies. In

Section 3, we outline the main feature of the model and contrast it with the prior literature. In Section 4, we discuss the main results and in Section 5 we conduct various sensitivity experiments to check the robustness of our baseline results and also present some extensions of the basic model. Section 6 concludes the paper.

\section{Basic Stylized Facts}

We first discuss some stylized facts that are relevant to monetary policy formulation in developing countries, starting with the share of food in household consumption expenditures 
and measures of the elasticity of food expenditures. ${ }^{1}$ Engel's law states that as average household income increases, the average share of food expenditure in total household expenditure declines. When this idea is extended to countries, we expect poorer countries to have a higher average share of food expenditure in total household expenditure. In Table 1, we present recent data on shares of food expenditure in total expenditure for selected developing and advanced economies. As expected, expenditure on food constitutes a much larger share of total household expenditure in developing relative to advanced economies.

Moreover, the income elasticity of food in developing economies is on average twice as large as that in advanced economies (0.63 versus 0.30 for a selected group of economies). We also note that the average price elasticity of food is much lower in absolute terms than the typical assumption of a unitary price elasticity, suggesting that food is a necessary good. As the share of expenditure on food is high in developing economies, the price elasticity of food is higher in these economies (average of about -0.38) but still lower than the value normally used in the literature. Low price and income elasticities of the demand for food have considerable significance for the choice of price index.

To examine the extent of credit constraints in developing countries, in Table 2 we present data from the World Bank (Demirguc-Kunt and Klapper, 2012) on the percentage of the adult population with access to formal finance (the share of the population using formal financial services) in developing countries. These data show that, on average, more than half of the population in developing countries lacks access to the formal financial system. By contrast, in advanced economies, nearly all households have such access.

Finally, we note that both food and nonfood inflation are higher on average in developing economies than in advanced economies. In the former group, food inflation is more volatile than nonfood inflation, consistent with the notion that food prices are more flexible than prices of other goods. Innovations to food price inflation are also more volatile

\footnotetext{
${ }^{1}$ Details on the data and stylized facts discussed in this section are in Anand and Prasad (2010).
} 
than innovations to nonfood inflation. These observations are consistent with other evidence that headline inflation is more volatile than core inflation in both developing and advanced economies (Anand and Prasad, 2010). The two measures of inflation exhibit a high degree of persistence in both sets of economies and, contrary to conventional wisdom, food price shocks tend to be quite persistent in developing economies (also see Walsh, 2011).

The main observations from this section are that, relative to households in advanced economies, those in developing economies have a higher share of food expenditures in total consumption expenditures, a higher income elasticity and lower price elasticity of food expenditures, and significantly lower access to formal financial institutions. These features potentially have implications for households' responses to changes in monetary policy.

\section{Model}

In this section, we develop a small open economy model incorporating features that are particularly relevant for developing economies. To examine whether the existing results about optimal inflation targeting are affected by these features, we adopt a model setting that is otherwise standard but broad enough to encompass features that previous authors have focused on.

\subsection{Households}

The economy consists of a continuum of infinitely-lived households of two types: (i) measure $\lambda>0$ of households producing food, the flexible price domestic good and (ii) measure $1-\lambda$ of households producing a continuum of monopolistically produced sticky price goods (nonfood) for domestic consumption and a flexible price good for export (nonfood exports). Our model is thus more general than that of Aoki (2001), which is for a closed economy, and allows for comparisons with Benigno's (2004) open economy setting. The 
model also embeds other key features of both Benigno (2004) and Mankiw and Reis (2003), whose models include multiple sectors with varying degrees of price rigidity.

We assume that labor is immobile across the food and nonfood sectors. ${ }^{2}$ The representative household, denoted by the superscript $i$, is indexed by $f$ (food sector) and $n$ (nonfood sector). Household $i$ maximizes the discounted stream of utility:

$$
E_{0} \sum_{t=0}^{\infty} \beta^{t}\left[U\left(C_{t}^{i}, N_{t}^{i}\right)\right]
$$

where $\beta \in(0,1)$ is the discount factor. The utility function takes the form:

$$
U\left(C_{t}^{i}, N_{t}^{i}\right)=u\left(C_{t}^{i}\right)-v_{i}\left(N_{t}^{i}\right), \quad i \in\{f, n\}
$$

where $u\left(C_{t}^{i}\right)$ is the utility of consumption and $v_{i}\left(N_{t}^{i}\right)$ is the disutility of labor supply. $C_{t}^{i}$ is the composite consumption index of household $i$ in period $t$, including food and nonfood goods. It is defined as

$$
C_{t}^{i}=\left[\gamma^{\frac{1}{\eta}}\left(C_{f, t}^{i}-C^{*}\right)^{\frac{\eta-1}{\eta}}+(1-\gamma)^{\frac{1}{\eta}}\left(C_{n, t}^{i}\right)^{\frac{\eta-1}{\eta}}\right]^{\frac{\eta}{\eta-1}}
$$

where $C_{f, t}^{i}$ represents food and $C_{n, t}^{i}$ is the total nonfood good, comprising both domestically produced sticky price nonfood goods $\left(C_{s, t}^{i}\right)$ and imported nonfood goods $\left(C_{m, t}^{i}\right)$. The composite index is given by

$$
C_{n, t}^{i}=\left[\zeta^{\frac{1}{\xi}}\left(C_{m, t}^{i}\right)^{\frac{\xi-1}{\xi}}+(1-\zeta)^{\frac{1}{\xi}}\left(C_{s, t}^{i}\right)^{\frac{\xi-1}{\xi}}\right]^{\frac{\xi}{\xi-1}}
$$

\footnotetext{
${ }^{2}$ This assumption reflects the large inter-sectoral wage differentials in developing economies. Galí et al. (2004) demonstrate that, even with free labor mobility, financial frictions lead to similar results as ours (aggregate demand increasing when the central bank raises the policy interest rate).
} 
$C_{s, t}^{i}$ is a continuum of the differentiated goods, given by:

$$
C_{s, t}^{i}=\left[\int_{0}^{1} c_{s, t}^{i}(z)^{\frac{\theta-1}{\theta}} d z\right]^{\frac{\theta}{\theta-1}}
$$

The elasticity of substitution between the flexible price and sticky price goods is given by $\eta \in(0,+\infty)$ and $\gamma \in(0,1)$ is the weight on food in the consumption index. $\zeta \in(0,1)$ is the share of imported nonfood goods in the nonfood consumption index, and $\xi \in(0,+\infty)$ is the elasticity of substitution between domestic nonfood and imported nonfood goods. $\theta>1$ is the elasticity of substitution between any two differentiated goods.

Since food is a necessity, households must consume a minimum amount $C^{*}$ of food for survival. We assume that all households always have enough income to buy the subsistence level of food. Even though this constraint does not bind, it alters the elasticity of substitution between food and nonfood and the marginal utility of food and nonfood consumption. This is one important departure from previous models that are mostly relevant for advanced economies, where food is a modest share of overall household expenditures.

The utility of consumption is given by $U\left(C_{t}^{i}\right)=\frac{C_{t}^{i 1-\sigma}}{1-\sigma}$, where $\sigma$ is the risk aversion factor. The disutility of labor supply for households in the food sector is given by $v_{f}\left(N_{t}^{f}\right)=\phi_{n}^{f} \frac{N_{t}^{f^{1+\psi}}}{1+\psi}$, where the parameter $\psi$ is the inverse of the Frisch elasticity and $\phi_{n}^{i}$ is the scaling factor. As households in the nonfood sector provide labor to sticky price firms (s) and export sector firms (x), aggregate labor supply is given by $v_{n}\left(N_{t}^{n}\right)=\phi_{n}^{n}\left[\int_{0}^{s} \frac{N_{t}^{s}(m)^{1+\psi}}{1+\psi} d m+\int_{s}^{1} \frac{N_{t}^{x}(m)^{1+\psi}}{1+\psi} d m\right]$, where $s$ is the share of nonfood households that work in the sticky price sector. ${ }^{3}$

\subsection{Budget Constraints and Financial Markets}

This section highlights the key difference between our model and those of previous authors who have studied optimal inflation targets. Households in the flexible price sector (food

\footnotetext{
${ }^{3}$ This specification implies local labor markets for the sticky price and export sectors and perfect risksharing among households in the nonfood sector (Ferrero et al., 2010).
} 
sector) do not have access to financial markets and they consume their wage income in each period. ${ }^{4}$ So these households are akin to "rule of thumb" consumers. A representative household in the food sector maximizes its lifetime utility given by equation (1) subject to the budget constraint:

$$
P_{t} C_{t}^{f}+P_{f, t} C^{*}=W_{f, t} N_{t}^{f}
$$

where $W_{f, t}$ is the nominal wage in the food sector. The total expenditure to attain a consumption index $C_{t}^{f}$ is given by $P_{t} C_{t}^{f}$ where $P_{t}$ is defined as

$$
P_{t}=\left[\gamma P_{f, t}^{1-\eta}+(1-\gamma) P_{n, t}^{1-\eta}\right]^{\frac{1}{1-\eta}}
$$

$P_{f, t}$ denotes the price of food and $P_{n, t}$, the price index of nonfood goods, is given by

$$
P_{n, t}=\left[\zeta P_{m, t}^{1-\xi}+(1-\zeta) P_{s, t}^{1-\xi}\right]^{\frac{1}{1-\xi}}
$$

and $P_{s, t}$ is the Dixit-Stiglitz price index defined as

$$
P_{s, t}=\left[\int_{0}^{1} X_{t}(z)^{1-\theta} d z\right]^{\frac{1}{1-\theta}}
$$

Households in the nonfood sector provide labor to firms in both the sticky price sector and the export sector. They can buy one-period nominal bonds and foreign bonds to smooth their consumption. A representative household in this sector maximizes lifetime utility given by equation (1) subject to the following budget constraint

$$
\begin{aligned}
& P_{t} C_{t}^{n}+P_{f, t} C^{*}+B_{t}+e_{t} B_{t}^{*}+\frac{\psi_{B}}{2} B_{t}^{* 2} \\
\leq & W_{s, t} \int_{0}^{s} N_{t}^{s}(m) d m+W_{x, t} \int_{s}^{1} N_{t}^{x}(m) d m+R_{t-1} B_{t-1}+e_{t} R_{t-1}^{*} B_{t-1}^{*}+\Pi_{t}^{s}
\end{aligned}
$$

\footnotetext{
${ }^{4}$ Data in Demirguc-Kunt and Klapper (2012) show that, in less developed economies, access to formal financial institutions is at least 10 percentage points lower in rural areas compared to urban areas. Basu and Srivastava (2005) document that 80 percent of individuals in India's agricultural sector have no access to formal finance. To keep the model tractable, there is no storage technology.
} 
where $B_{t}$ and $B_{t}^{*}$ represents the quantity of one-period nominal risk free discount bonds denominated in domestic and foreign currency, respectively. The gross nominal interest rates for those two types of bonds are denoted by $R_{t}$ and $R_{t}^{*}$, respectively. ${ }^{5} W_{x, t}$ and $W_{s, t}$ are the nominal wages in the export and sticky price sectors and $N_{t}^{x}$ and $N_{t}^{s}$ are the labor supply in these two sectors. $\Pi_{t}^{s}$ is the profit from firms in the sticky price sector.

\subsection{Production}

Each household in the food sector owns one firm and produces food using a linear technology in labor $y_{f, t}=A_{f, t} N_{t}^{f}$, subject to a common productivity shock $A_{f, t}$. Firms in this sector are price takers and, given a market price $P_{f, t}$, the zero profit condition determines labor demand.

Similarly, firms in the sticky price sector use a linear technology in labor $y_{s, t}(z)=$ $A_{s, t} N_{t}^{s}(z)$ and are subject to a common productivity shock $A_{s, t}$. Following Calvo (1983), we assume that a fraction $\alpha \in(0,1)$ of firms cannot change their price in each period. ${ }^{6}$ Firms that are free to change the price at time $t$ choose a price $X_{t}$ to maximize the discounted profit stream given by:

$$
\max _{X_{t}(z)} E_{t} \sum_{j=0}^{\infty}(\alpha \beta)^{j} Q_{t, t+j}\left[y_{t, t+j}^{s}(z)\left(X_{t}(z)-M C_{t}^{s}\right)\right]
$$

where $Q_{t, t+j}$ is the stochastic discount factor, $X_{t}$ is the price of the variety produced by firm $z$, and $y_{t, t+j}^{s}$ is the output of firm in period $t+j$ when it has set its price in period $t$. Furthermore, the marginal cost is given by $M C_{t}^{s}=\frac{W_{t}^{s}}{A_{t}^{s}}$.

Firms in the export sector also use a linear technology $y_{x, t}=A_{x, t} N_{t}^{x}$ and face an exogenous price level every period. ${ }^{7}$ Firms in this sector are assumed to be price takers. Import

\footnotetext{
${ }^{5}$ We also include a small quadratic portfolio holding cost for foreign bond holdings, as suggested by Schmitt-Grohé and Uribe (2003), only to induce stationarity.

${ }^{6}$ For an alternative motivation of price rigidity based on sticky information, see Mankiw and Reis (2002).

${ }^{7}$ We model the export sector in a manner similar to Mendoza (1995) and Devereux et al. (2006).
} 
prices are exogenous and follow the law of one price. The terms of trade shock, which links import and export prices, determines the export price. Thus, $P_{x, t}=S_{t} P_{m, t}$, where $S_{t}$ is the terms of trade. Given export prices, the firms' cost minimization problem determines wages and, therefore, the labor demand in the sector.

\subsection{Inflation and Monetary Policy Rule}

We define gross headline inflation as $\pi_{t}=\frac{P_{t}}{P_{t-1}}$, gross inflation in the sticky price sector as $\pi_{s, t}=\frac{P_{s, t}}{P_{s, t-1}}$, and gross imported goods inflation is defined as $\pi_{m, t}=\frac{P_{m, t}}{P_{m, t-1}}$. The steady state is characterized by constant prices (zero inflation) and no price stickiness in the economy. ${ }^{8}$ The central bank sets the short-term nominal interest rate $\left(R_{t}\right)$ according to the following version of a Taylor (1993) rule:

$$
\log \left(\frac{R_{t}}{\bar{R}}\right)=\rho \log \left(\frac{R_{t-1}}{\bar{R}}\right)+(1-\rho)\left[\phi_{\pi} \log \left(\frac{\pi_{t}^{*}}{\bar{\pi}}\right)+\phi_{y} \log \left(\frac{y_{t}}{\bar{y}}\right)\right]
$$

where $\bar{y}, \bar{\pi}$ and $\bar{R}$ are the steady state values of output, inflation, and the nominal interest rate, respectively. The term $\rho$ represents the central banker's preference for interest rate smoothing. ${ }^{9} \phi_{\pi}$ and $\phi_{y}$ are the weights on inflation and output gap assigned by the policy makers. Setting the parameter $\phi_{y}=0$ implies strict inflation targeting regimes. We characterize core inflation as the inflation in the sticky price sector, $\pi_{s, t}$, and headline inflation as the overall inflation, $\pi_{t}$, for our policy experiments. In addition, for the computation of the optimal inflation target, we use an inflation target given by

$$
\pi_{t}^{*}=\rho_{\pi_{s}} \pi_{s, t}+\rho_{\pi_{f}} \pi_{f, t}+\left(1-\rho_{\pi_{s}}-\rho_{\pi_{f}}\right) \pi_{m, t}
$$

\footnotetext{
${ }^{8}$ Our model has zero trend inflation. Ascari (2004) shows that, in the absence of full indexation, the Calvo staggered price model is not super-neutral when trend inflation is considered.

${ }^{9}$ Interest rate smoothing behavior by central banks and its benefits are well documented (Clarida et al., 1998). Mohanty and Klau (2005) find that developing countries central banks also put substantial weight on interest rate smoothing. The formulation of the monetary policy rule with interest rate smoothing is similar to that used by Clarida et al. (1999).
} 


\subsection{Exogenous Shock Processes}

We assume that productivity shocks in the food sector follow an AR(1) process. Firms in the sticky price sector face similar $\mathrm{AR}(1)$ productivity shocks but are also subject to mark-up shocks that reflect rent-seeking behavior that is typical in developing economies. This is a departure from models that only feature productivity shocks in the relevant sectors. Firms in the export sector face terms of trade shocks as they are price takers and face international market prices that are determined exogenously. This shock is similar to a productivity shock to the production of export goods. The structure of the export sector allows us to encompass the setup of Frankel (2008). To sum up, there are four shocks in the model, with innovations to each of them drawn from i.i.d. normal distributions:

$$
\begin{array}{llll}
\text { Productivity shock, food: } & \log \left(\frac{A_{f, t}}{\overline{A_{f}}}\right)=\rho_{a}^{f} \log \left(\frac{A_{f, t-1}}{\bar{A}_{f}}\right)+\varepsilon_{t}^{f}, & \varepsilon_{t}^{f} \sim N\left(0, \sigma_{a}^{f}\right) \\
\text { Productivity shock, sticky price goods: } & \log \left(\frac{A_{s, t}}{\bar{A}_{s}}\right)=\rho_{a}^{s} \log \left(\frac{A_{s, t-1}}{\bar{A}_{s}}\right)+\varepsilon_{t}^{s}, & \varepsilon_{t}^{s} \sim N\left(0, \sigma_{a}^{s}\right) \\
\text { Mark-up shock, sticky price goods: } & \log \left(\frac{\tau_{t}}{\bar{\tau}}\right) & =\rho_{\tau} \log \left(\frac{\tau_{t-1}}{\bar{\tau}}\right)+\varepsilon_{t}^{\tau}, & \varepsilon_{t}^{\tau} \sim N\left(0, \sigma_{\tau}\right) \\
\text { Terms of trade shock, nonfood exports: } & \log \left(\frac{S_{t}}{\bar{S}}\right)=\rho_{s} \log \left(\frac{S_{t-1}}{\bar{S}}\right)+\varepsilon_{t}^{\sigma}, & \varepsilon_{t}^{\sigma} \sim N\left(0, \sigma_{s}\right)
\end{array}
$$

\subsection{Welfare Evaluations}

Our objective is to determine the policy rule that yields the highest level of lifetime utility as a weighted sum of households' welfare, which can be written as $V_{\text {total }}=\lambda V_{t}^{f}+(1-\lambda) V_{t}^{n}$. We compute the second-order accurate consumer welfare measure under different monetary policy regimes as in Schmitt-Grohé and Uribe $(2004,2007) \cdot{ }^{10}$ Since the prior literature concludes that strict core inflation targeting is the welfare maximizing policy rule, we use that as the benchmark to evaluate the welfare gains (or losses) associated with alternative policy regimes. We define $\omega$, the welfare gain from adopting an alternative policy rule, as the fraction that has to be added to the strict core inflation targeting regime's (denoted by $r$ ) consumption process to yield a level of aggregate welfare equivalent to that under regime

\footnotetext{
${ }^{10}$ For a justification of this approach and more details, see Anand and Prasad (2010).
} 
a. That is,

$$
V_{0}^{a}=E_{0} \sum_{t=0}^{\infty} \beta^{t} U\left((1+\omega) C_{t}^{r}, N_{t}^{r}\right)
$$

A positive value of $\omega$ means that welfare is higher under the alternative policy rule. The welfare gain $\omega$ is given by

$$
\omega=\left[\frac{V_{0}^{a}+D_{0}^{r}}{V_{0}^{r}+D_{0}^{r}}\right]^{\frac{1}{1-\sigma}}-1
$$

where $D_{0}^{r}=E_{0} \sum_{t=0}^{\infty} \beta^{t}\left[\phi_{n} \frac{\left(N_{t}^{r}\right)^{1+\psi}}{1+\psi}\right]$. A value of $\omega * 100=1$, represents a gain of one percentage point of permanent consumption under the alternative policy regime.

\subsection{Parameter Selection}

Parameter selection for the model is a challenging task. There is no consensus on the values of some parameters and those used in the literature are mostly based on micro data from advanced countries. We pick baseline parameters from the existing literature and then do extensive sensitivity analysis with respect to the choice of key parameters.

We choose $\beta=0.99$, which amounts to an annual real interest rate of 4 percent. We assume that $\lambda=0.4$, implying that 40 percent of households in the economy are credit constrained, consistent with the data in Table 2. We use $\sigma=2$ as the baseline value of the risk aversion parameter, a value most commonly used in the literature on developing economies (Aguiar and Gopinath, 2007; Devereux et al., 2006; García-Cicco et al., 2010).

Following Basu and Fernald (1995) and Basu (1996), we choose $\theta=11$ (elasticity of substitution between the differentiated goods), implying a markup of 10 percent in the steady state. We set the probability that a price does not adjust in a given period $(\alpha)$ at 0.66 (Rotemberg and Woodford, 1997). This implies that prices remain fixed for a mean duration of 3 quarters, consistent with the microeconomic evidence for both developing and advanced economies. ${ }^{11}$ The appropriate value of the Frisch elasticity $\left(\frac{1}{\psi}\right)$ is both important

\footnotetext{
${ }^{11}$ Evidence from Brazil (Gouvea, 2007), Chile (Medina et al., 2007), Mexico (Gagnon, 2009), and South Africa (Creamer and Rankin, 2008) indicates that the frequency of price adjustment is much higher for food
} 
and controversial. For our benchmark case we assume it to be $0.33(\psi=3) .{ }^{12}$ For the monetary policy parameters, we follow Galí et al. (2004) and Mohanty and Klau (2005) and choose $\rho=0.7, \phi_{\pi}=2$, and $\phi_{y}=0.5$.

An important feature of developing countries is the high share of food expenditure in total household expenditures. To calibrate the subsistence level food consumption parameter $C^{*}$ and the weight on food in the consumption index $\gamma$, we assume the average expenditure on food is around 42 percent (consistent with household surveys in developing countries). We further assume that on average one third of households' steady state food consumption is required for subsistence, enabling us to match estimates of the income elasticity of food consumption (about two-thirds). ${ }^{13}$ As the demand for food is inelastic, we set $\eta=0.6$ for the baseline case. Along with the subsistence level of food consumption, this implies a price elasticity of the demand for food of around -0.3 in the steady state, which is close to the USDA estimate.

The major argument in favor of excluding food from the core price index is that the shocks to that sector are seasonal and transient. We set the value of the AR (1) coefficient of the food sector shock at 0.25 (implying that the shock has low persistence, which seems reasonable given the heavy dependence of agriculture on transitory weather conditions). Following the literature, we set the value of the $\mathrm{AR}(1)$ coefficient of the nonfood sector shock at 0.9 (Aguiar and Gopinath, 2007). The volatility of productivity shocks in developing countries is higher than in advanced countries (Pallage and Robe, 2003; García-Cicco et al., 2010). We set the standard deviation of the food productivity shock $\sigma_{a}^{f}=0.03$ and the standard deviation of the nonfood productivity shock $\sigma_{a}^{s}=0.02$. We follow Devereux et al. (2006) in calibrating the persistence and standard deviation of the terms of trade shock and choose $\rho_{s}=0.77$

than for nonfood products and that price adjustments are less frequent during periods of low to moderate inflation. Since our model has no trend inflation and we impose price stickiness only in the nonfood sector, our parameter choice is consistent with the results of these studies.

${ }^{12}$ Christiano et al. (1996) estimate it to be 0.25; Rotemberg and Woodford (1997) estimate it to be 0.40.

${ }^{13}$ The income elasticity of food consumption is equal to one minus the subsistence ratio. 
and $\sigma_{s}=0.013$. We set the persistence of the mark-up shock $\rho_{\tau}=0.9$ and the standard deviation parameter $\sigma_{\tau}=0.01$.

\section{Baseline Results}

While it is not our objective to match specific moments, the incomplete markets version of our model more closely matches the properties of business cycle fluctuations in developing economies relative to advanced economies. ${ }^{14}$ For instance, with the baseline parameters and shock processes, the incomplete markets model delivers inflation (for both food and nonfood commodities) that is higher and more volatile than in the complete markets model. This is consistent with the empirical findings of Fraga et al. (2004), Bowdler and Malik (2005), and Pétursson (2008) that developing economies have more volatile inflation than advanced ones. Consumption is more volatile than output in the incomplete markets model, while the reverse is true in the complete markets model. This matches the findings of Aguiar and Gopinath (2007) and Kose et al. (2009) that consumption is more volatile than output in developing economies, while the opposite holds (as anticipated based on the consumption smoothing motive) in advanced economies.

We now present the conditional welfare gains associated with different policy rules in our model. We include all four shocks-productivity shocks to two sectors, mark-up shocks, and terms of trade shocks-when we do the welfare calculations discussed below.

Table 4 shows the welfare comparisons from targeting different price indices under complete and incomplete market settings, and also the sectoral weights for constructing the optimal price index in each case. With complete markets, the optimal price index puts the entire weight on the sticky price sector, with zero weights on food and traded goods, making it identical to core inflation targeting. Targeting headline inflation slightly reduces welfare. Thus, under complete markets, the choice of targeting strict core inflation is the best policy

\footnotetext{
${ }^{14}$ These results are not reported in detail here but are available from the authors.
} 
and dominates targeting of broader price indexes, as in Aoki (2001) and Benigno (2004).

However, with incomplete markets, this result no longer holds. The second column of Table 4 shows that headline inflation targeting is now welfare improving relative to core inflation targeting. Targeting the optimal price index yields a slightly higher welfare gain than targeting headline inflation. ${ }^{15}$ The optimal price index assigns a weight of two-thirds to the sticky price sector and one-third to food prices. This result is a marked departure from the prior literature based on complete markets, wherein the optimal weight on food prices would be zero. On the other hand, it is consistent with the Benigno (2004) result (and, implicitly, the results of Aoki, 2001, and Mankiw and Reis, 2003) that the weight on the traded goods sector is zero. That sector has flexible prices and agents in that sector have access to financial markets, so the classical result is confirmed.

To investigate these results more carefully, we analyze the responses of key variables to a food productivity shock because shocks to that sector highlight the relevance of market completeness. Figure 1 plots the impulse responses of various macroeconomic variables to a one percent negative food productivity shock under complete markets. Each variable's response is expressed as the percentage deviation from its steady state level. Impulse responses under a strict core inflation targeting rule are shown by the solid lines. The dashed lines are impulse responses under a strict headline inflation targeting rule. The strict headline inflation targeting regime results in a slightly higher volatility of consumption and output. Also, the policy response is more aggressive under strict headline inflation targeting, which leads to a further decline in output. These results are similar to those documented in the existing literature on inflation targeting.

Following an increase in inflation, the central bank raises interest rates, reducing aggre-

\footnotetext{
${ }^{15}$ The welfare gains are larger than those typically reported in models calibrated to advanced economy data. One reason is that developing economies have more volatile output and consumption than advanced economies. Secondly, the financial frictions that we include our model imply that monetary policy can have an even greater impact in terms of reducing the consumption volatility of different household types, which can in some cases be higher than aggregate consumption volatility.
} 
gate demand (as consumers postpone their consumption following an increase in interest rates) and, thus, inflation. So, under complete markets, stabilizing core inflation is equivalent to stabilizing the output gap (Aoki, 2001) and there are no additional welfare gains from adopting headline inflation targeting. Thus, core inflation targeting is the welfare maximizing policy choice for the central bank.

However, in the presence of credit constrained consumers, headline inflation targeting appears to be a better policy choice. Figure 2 plots the impulse responses of various macroeconomic variables to a one percent negative food productivity shock under incomplete markets. Aggregate demand responds differently to monetary tightening under strict core inflation targeting and headline inflation targeting. The central bank is now able to effectively control aggregate demand by increasing interest rates only when it targets headline inflation. Aggregate demand, instead of going up slightly, goes up sharply in response to the shock if the central bank follows strict core inflation targeting. Thus, headline inflation targeting outperforms core inflation targeting as the former is more effective at stabilizing output.

In order to examine the mechanics behind this result, we look at the properties of aggregate demand under incomplete markets. In the presence of financial frictions, the consumption choices of different households vary (as opposed to complete markets, where the consumption choice of each household is identical). While the consumption demand of unconstrained households is responsive to interest rates (as they optimize intertemporally), the consumption demand of credit-constrained households is independent of interest rate changes and depends only on their current period wage income. Since only a fraction of aggregate demand is influenced by interest rate changes, a monetary tightening does not automatically mitigate the increase in aggregate demand. The response of aggregate demand crucially depends on the behavior of credit-constrained households.

Figure 2 shows that, following a negative shock to food productivity, the central bank raises the interest rate, lowering the demand of unconstrained households (as it is optimal 
for them to postpone consumption). However, it has no bearing on the demand of creditconstrained consumers. An increase in the relative price of food following a negative food productivity shock increases the wage income and, therefore, consumption demand of creditconstrained households. Thus, the demand of the two types of households moves in opposite directions following a negative shock to food productivity.

Which of the two demands dominates is determined by the policy regime. Under core inflation targeting, the increase in food prices (and, therefore, the wage income of food sector households) is higher than under headline inflation targeting. This higher wage income translates into higher consumption demand by credit-constrained consumers (who consume all of their current wage income), more than compensating for the lower consumption demand of unconstrained consumers. Consequently, aggregate demand rises. By contrast, when the central bank targets headline inflation, price increases in the food sector are lower and the rise in income and, therefore, the increase in consumption demand in that sector is smaller. Thus, monetary intervention is effective in achieving its objective of controlling aggregate demand only when the central bank targets headline inflation.

To formalize the above arguments, we examine the log-linearized aggregate demand equation, which is given by: ${ }^{16}$

$$
\hat{c}_{t}=-\frac{(1-\lambda) \zeta_{s}}{\sigma} E_{t}\left(\hat{R}_{t}-\hat{\pi}_{t+1}\right)+E_{t} \hat{c}_{t+1}-\lambda \zeta_{f} E_{t} \Delta \hat{c}_{f, t+1}
$$

where $\zeta_{f}=\frac{\overline{C_{f}}}{\bar{C}}$ is the steady state share of food sector households' consumption and $\zeta_{s}=\frac{\bar{C}_{s}}{\bar{C}}$ is the steady state share of nonfood sector households' consumption.

Furthermore, from the optimal labor supply of food sector households, we have:

$$
\hat{c}_{f, t}=\frac{1+\frac{a}{\psi}}{1+\frac{a \sigma}{\psi}} \hat{x}_{f, t}+\frac{a\left(1+\frac{1}{\psi}\right)}{1+\frac{a \sigma}{\psi}} \hat{A}_{f, t}
$$

\footnotetext{
${ }^{16}$ Aggregate demand is the sum of the log-linearized consumption demand of households in the two sectors. Variables with a hat denote log deviations from corresponding steady state values.
} 
where $a=\frac{\bar{x}_{f} \bar{y}_{x}}{\bar{C}_{f}}>1$.

Equations (16) and (17) suggest that, in the presence of credit-constrained consumers, there is a link between aggregate demand and the relative price of food $\left(x_{f, t}\right)$. In this setting, relative prices affect aggregate demand in addition to aggregate supply. ${ }^{17}$ Thus, the presence of financial frictions implies that managing aggregate demand requires the central bank to choose a policy regime that would limit the rise in wages of credit-constrained consumers (and, therefore, the increase in their demand).

\subsection{Alternative Monetary Policy Rules}

Next, we evaluate a broader range of monetary policy rules that are employed by developing (and advanced) economy central banks. The monetary policy rule employed even by inflation targeting central banks typically includes the output gap, so we now consider whether flexible inflation targeting delivers better welfare outcomes than strict inflation targeting.

The first row of Table 5 shows the baseline result-all three inflation targets (optimal, headline and core) under strict inflation targeting, i.e., with zero weight on the output gap. In the second row, we compare all three inflation targets (core, headline, and optimal weights) under flexible inflation targeting, i.e., with a positive weight on the output gap. The results show that the ordering of the different rules in terms of welfare gains relative to core inflation targeting is preserved. Moreover, the weights on the different sectors in the optimal price index are essentially the same.

In the third row, we compare flexible headline and flexible optimal inflation targeting against strict core inflation targeting. The two flexible inflation targeting regimes still outperform strict core inflation targeting. However, comparing the first and third rows, it is evident that adding the output gap into the monetary policy rule leads to lower welfare gains

\footnotetext{
${ }^{17}$ Under complete markets, relative prices only affect aggregate supply (Aoki, 2001).
} 
than strict targeting versions of those rules. The reason is that in the sticky price sector the output gap, defined as the level of output relative to trend, and inflation move in the same direction. A negative productivity shock leads to a drop in output and an increase in inflation in this sector. Therefore, adding the output gap into the monetary policy rule weakens the central bank's response to deviations of inflation from the target value. To confirm this, we also conducted an experiment where we included the output gap coefficient in the search for the optimal rule. Consistent with the results noted above, the optimal coefficient for the output gap is zero. ${ }^{18}$

\section{$5 \quad$ Sensitivity Analysis and Extensions}

In this section, we report results from a variety of experiments to test the robustness of our results to changes in the values of key parameters and certain aspects of the structure of the model. Our results held up quite well to changes in values of most parameters, so in the discussion below we focus on the elements of our model that represent significant deviations from the prior literature. It should be noted that, since the steady state values of the models differ, it is only possible to make a comparison across regimes and not across different models.

\subsection{Sensitivity to Key Parameters}

One of the key parameter settings in the model is the proportion of households in the economy that are in the food sector and face credit constraints. As the share of households in this sector rises, welfare gains from headline inflation or optimal inflation targeting decline relative to core inflation targeting (see Table 6, Panel A). This might seem counter-intuitive

\footnotetext{
${ }^{18}$ This finding is consistent with the result of Schmitt-Grohé and Uribe (2007). We also experimented with including the real exchange rate directly in the optimal inflation target, and found that the coefficient on this variable was zero (we tried including it in different ways-the current level, lagged level, and changes). Similarly, when we added the export price to the optimal inflation target, the weight on it was zero.
} 
as these households lack access to credit. The mechanism for this result is as follows. When the share of rural households is larger, under our parameter assumptions they will be poorer on average while the nonfood sector households will be richer. For a given drop in agricultural output, the relative price of food goes up by less when the consumption of food (above the subsistence level) by nonfood sector households is larger. When the share of rural households is small, the food consumption of households in the nonfood sector is also small in the steady state. Therefore, to accommodate a drop in food production, the relative price responds sharply. ${ }^{19}$

An important assumption in the model is the subsistence level of food. As noted earlier, this constraint does not bind in equilibrium but reduces the elasticity of substitution between food and nonfood goods. When there is no subsistence level of food consumption, the weight of food in the optimal inflation target is small and core inflation targeting actually delivers higher welfare than headline inflation (see Table 6, Panel B). As the subsistence level goes up, the weight of food in the optimal inflation index rises and core inflation targeting becomes inferior to headline inflation targeting. Note that in our model the total share of food consumption is pinned down based on empirical estimates for developing economies. A higher subsistence level of food therefore implies a lower level of nonsubsistence food consumption. Therefore, for any given amount of drop in the food output, market clearing necessitates a larger increase in the relative price of food. As a result, the higher is the subsistence level of food, the more volatile the impulse responses will be and the larger the welfare gain from headline inflation targeting.

An alternative approach to including a subsistence level of food in the utility function would be to directly pick a lower value for the elasticity of substitution between food and nonfood goods. Dropping the assumption that there is a subsistence level of food and

\footnotetext{
${ }^{19}$ Reducing the share of food sector households even further leads to implausibly large welfare gains, but this is because we have pinned down the average share of food expenditures in total household expenditures to be 0.42 . Economies with small shares of rural households tend to be richer economies with substantially lower food shares in total expenditure.
} 
lowering the elasticity to 0.38 yielded results similar to our baseline results. However, our approach is more realistic for developing economies. Empirical evidence shows that the income elasticity of food consumption is smaller than one in developing economies, which suggests it is more likely that food consumption is driven by the subsistence level. ${ }^{20}$

Another crucial parameter in the model is the share of food in total household consumption expenditures. When this share is small, the optimal inflation target puts most of the weight on the sticky price sector. Core inflation targeting then delivers higher welfare than headline inflation targeting, and the gains from targeting the optimal inflation index are modest. As the food share rises, the optimal inflation index involves an increasing weight on food prices. When food accounts for half of total consumption expenditures on average, the gains from headline inflation targeting become large and the optimal inflation index puts nearly the entire weight on food prices. This result appears at odds with one of the results in Mankiw and Reis (2003). They find that "the more important a price is in the consumer price index, the less weight that sector's price should receive in the stability price index." The incomplete markets structure of our model and the low elasticity of substitution between food and nonfood account for the difference between our result and theirs. However, our result that the weight on food prices is zero is true when markets are complete irrespective of the share of food in consumption expenditures, consistent with a different proposition in their paper-that sectors with more flexible prices should get a lower weight.

We also experimented with changing the degree of price rigidity in the sticky price sector (see Table 6, Panel C). Consistent with Mankiw and Reis (2003) and Benigno (2004), we find that the weight of the sticky price sector in the optimal price index increases with the degree of price stickiness.

\footnotetext{
${ }^{20}$ See Anand and Prasad (2010) for more discussion. As noted earlier, the income elasticity of food consumption is equal to one minus the subsistence ratio so the model without subsistence level assumption cannot match the data for developing countries.
} 


\subsection{Financial Frictions}

In the baseline model, we assume that food sector households face strong financial frictions, turning them into hand-to-mouth consumers. We now relax this assumption by introducing a portfolio holding cost for these households, enabling us to vary the extent of (common) financial frictions they face. ${ }^{21}$ When the portfolio holding cost is zero, rural households have the same degree of access to the bond market as nonfood sector households. It is important to note that this is not equivalent to having complete financial markets. When the portfolio holding cost is very high, rural households hold zero bonds and the economy converges to the baseline case.

In the full access (but still not complete markets) scenario, food prices do enter with a positive weight in the optimal price index, although this weight is substantially smaller than in the baseline incomplete markets scenario. However, the welfare gain from targeting the optimal price index is small relative to core inflation targeting as the bonds give food sector households the ability to smooth consumption intertemporally although they cannot fully insure against sector-specific shocks.

\subsection{Common Productivity Shocks}

Finally, we consider the case where there are only aggregate rather than sector-specific productivity shocks. To this point, we have focused on the impact of a shock to productivity in the flexible price sector as it most clearly illustrates the point about what monetary policy rule is better in response to a shock to the flexible price part of the economy. Of course, while the impulse responses that we analyzed highlight different models' responses to only a food productivity shock, the simulation results include all shocks.

We recomputed the model with a productivity shock common to the food and the nonfood domestic goods sectors (and, as before, markup and terms of trade shocks as well).

\footnotetext{
${ }^{21}$ The results discussed in this subsection and the next one are available from the authors.
} 
Intuitively, this should increase the welfare gain from targeting inflation in the headline CPI or the optimal price index as there are no longer any shocks specific to the rigid price sector. This is indeed what we find, confirming our main results. The results were similar whether the common productivity shock was transitory (food sector shock) or more persistent (sticky price sector shock). Besides, food prices consistently have a significant weight in the optimal inflation target.

\section{Concluding Remarks}

Previous research has concluded that optimal monetary policy should focus on offsetting nominal rigidities by stabilizing core inflation. However, those results rely on the assumption that markets are complete and that price stickiness is the only source of distortion in the economy. In this paper, we have developed a more realistic model for developing economies that has the following key features-incomplete markets with credit-constrained consumers; households requiring a minimum subsistence level of food; low price elasticity of the demand for food; and a high share of expenditure on food in households' total consumption expenditure. We nest models such as those of Aoki (2001) and Benigno (2004) as special cases of our model.

We show that the classical result about the optimality of core inflation targeting can be overturned by introducing financial frictions. In the presence of credit-constrained consumers, targeting core inflation no longer maximizes welfare. Moreover, stabilizing inflation is not sufficient to stabilize output when markets are not complete. Under these conditions, headline inflation targeting improves welfare. Our model also allows us to compute optimal price indexes that maximize welfare. The optimal price index includes a positive weight on food prices but, unlike headline inflation, generally assigns zero weight to import prices. This is because agents in that sector have access to financial markets and, unlike in the case 
of food, the price elasticity of the demand for goods produced in this sector is high. ${ }^{22}$

One possible extension of our model is to include money explicitly. While this provides a saving mechanism for hand-to-mouth consumers, it would also strengthen the case for headline inflation targeting to preserve the value of monetary savings. Another extension would be to include physical capital in the model. This highlights a practical dilemma that developing economy central banks often grapple with in pursuit of their objective of price stability. For instance, raising policy rates to deal with surging food price inflation can hurt industrial activity. While raising interest rates in response to a transitory negative shock to agricultural sector productivity might seem counter-intuitive, our results suggest that such a policy could in fact be welfare improving in an incomplete markets setting in which food consumption accounts for a large share of household consumption expenditures.

\footnotetext{
${ }^{22}$ Looking beyond the CPI, Erceg et al. (2000) find that in the presence of wage stickiness optimal monetary policy should target the nominal wage. Reinterpreting the sectors in the Mankiw-Reis (2003) model as including a labor sector with nominal wage rigidities yields similar results.
} 


\section{References}

Aguiar, Mark and Gita Gopinath (2007), "Emerging market business cycles: The cycle is the trend." Journal of Political Economy, 115, 69-102.

Anand, Rahul and Eswar S Prasad (2010), Optimal price indices for targeting inflation under incomplete markets. NBER Working Paper No. 16290.

Aoki, Kosuke (2001), "Optimal monetary policy responses to relative-price changes." Journal of Monetary Economics, 48, 55-80.

Ascari, Guido (2004), "Staggered prices and trend inflation: some nuisances." Review of Economic Dynamics, 7, 642-667.

Basu, Priya and Pradeep Srivastava (2005), Scaling-up microfinance for India's rural poor. World Bank Policy Research Working Paper No. 3646.

Basu, Susanto (1996), "Procyclical productivity: increasing returns or cyclical utilization?" The Quarterly Journal of Economics, 111, 719-751.

Basu, Susanto and John G Fernald (1995), "Are apparent productive spillovers a figment of specification error?" Journal of Monetary Economics, 36, 165-188.

Benigno, Pierpaolo (2004), "Optimal monetary policy in a currency area." Journal of International Economics, 63, 293-320.

Bowdler, Christopher and Adeel Malik (2005), "Openness and inflation volatility: panel data evidence." University of Oxford. Working paper.

Calvo, Guillermo A (1983), "Staggered prices in a utility-maximizing framework." Journal of Monetary Economics, 12, 383-398.

Catão, Luis and Roberto Chang (2010), World food prices and monetary policy. NBER Working Paper No. 16563.

Christiano, Lawrence J, Martin Eichenbaum, and Charles Evans (1996), "The effects of monetary policy shocks: evidence from the flow of funds." The Review of Economics and Statistics, 78, 16-34.

Clarida, Richard, Jordi Galí, and Mark Gertler (1998), "Monetary policy rules in practice: some international evidence." European Economic Review, 42, 1033-1067.

Clarida, Richard, Jordi Galí, and Mark Gertler (1999), "The science of monetary policy: a new keynesian perspective." Journal of Economic Literature, 37, 1661-1707.

Creamer, Kenneth and Neil A Rankin (2008), Price setting in South Africa 2001-200\%stylised facts using consumer price micro data. Manuscript, University of the Witwaterstrand. 
Demirguc-Kunt, Asli and Leora Klapper (2012), Measuring financial inclusion: the global findex database. World Bank Policy Research Working Paper No. 6025.

Devereux, Michael B, Philip R Lane, and Juanyi Xu (2006), "Exchange rates and monetary policy in emerging market economies." The Economic Journal, 116, 478-506.

Erceg, Christopher J, Dale W Henderson, and Andrew T Levin (2000), "Optimal monetary policy with staggered wage and price contracts." Journal of Monetary Economics, 46, 281-313.

Ferrero, Andrea, Mark Gertler, and Lars EO Svensson (2010), "Current account dynamics and monetary policy." In International Dimensions of Monetary Policy (Jordi Galí and Mark Gertler, eds.), 199-244, University of Chicago Press.

Fraga, Arminio, Ilan Goldfajn, and Andre Minella (2004), "Inflation targeting in emerging market economies." In NBER Macroeconomics Annual 2003, Volume 18 (Mark Gertler and Kenneth Rogoff, eds.), 365-416, The MIT Press.

Frankel, Jeffrey A (2008), "The effect of monetary policy on real commodity prices." In Asset Prices and Monetary Policy (John Y. Campbell, ed.), 291-333, University of Chicago Press.

Gagnon, Etienne (2009), "Price setting during low and high inflation: evidence from mexico." The Quarterly Journal of Economics, 124, 1221-1263.

Galí, Jordi, J David López-Salido, and Javier Vallés (2004), "Rule-of-thumb consumers and the design of interest rate rules." Journal of Money, Credit and Banking, 36, 739-763.

García-Cicco, Javier, Roberto Pancrazi, and Martín Uribe (2010), "Real business cycles in emerging countries?" American Economic Review, 100, 2510-31.

Goodfriend, Marvin and Robert King (1997), "The new neoclassical synthesis and the role of monetary policy." In NBER Macroeconomics Annual 1997, Volume 12 (Ben S. Bernanke and Julio J. Rotemberg, eds.), 231-296, MIT Press.

Goodfriend, Marvin and Robert G King (2001), "The case for price stability." In The First ECB Central Banking Conference: Why Price Stability? (Alicia G. Herrero, Vitor Gaspar, Lex Hoogduin, Julian Morgan, and Bernhard Winkler, eds.), European Central Bank.

Gouvea, Solange (2007), Price rigidity in Brazil: evidence from CPI micro data. Banco Central de Brasil Working Paper No. 143.

Kose, M Ayhan, Eswar S Prasad, and Marco E Terrones (2009), "Does financial globalization promote risk sharing?" Journal of Development Economics, 89, 258-270.

Mankiw, N Gregory and Ricardo Reis (2002), "Sticky information versus sticky prices: a proposal to replace the new keynesian phillips curve." Quarterly Journal of Economics, $117,1295-1328$. 
Mankiw, N Gregory and Ricardo Reis (2003), "What measure of inflation should a central bank target?" Journal of the European Economic Association, 1, 1058-1086.

Medina, Juan Pablo, David Rappoport, and Claudio Soto (2007), Dynamics of price adjustments: evidence from micro level data for chile. Central Bank of Chile Working Paper No. 432.

Mendoza, Enrique G (1995), "The terms of trade, the real exchange rate, and economic fluctuations." International Economic Review, 36, 101-137.

Mishkin, Frederic S (2007), "Inflation dynamics." International Finance, 10, 317-334.

Mishkin, Frederic S (2008), Does stabilizing inflation contribute to stabilizing economic activity? NBER Working Paper No. 13970.

Mohanty, Madhusudan S and Marc Klau (2005), "Monetary policy rules in emerging market economies: issues and evidence." In Monetary Policy and Macroeconomic Stabilization in Latin America (Rolf J Langhammer and Lúcio Vinhas de Souza, eds.), 205-245, Springer.

Pallage, Stephane and Michel A Robe (2003), "On the welfare cost of economic fluctuations in developing countries." International Economic Review, 44, 677-698.

Pétursson, Thórarinn G (2008), How hard can it be? inflation control around the world. Central Bank of Iceland, Economics Department.

Rotemberg, Julio and Michael Woodford (1997), "An optimization-based econometric framework for the evaluation of monetary policy." In NBER Macroeconomics Annual 1997, Volume 12 (Ben S. Bernanke and Julio J. Rotemberg, eds.), 297-361, MIT Press.

Schmitt-Grohé, Stephanie and Martın Uribe (2003), "Closing small open economy models." Journal of International Economics, 61, 163-185.

Schmitt-Grohé, Stephanie and Martın Uribe (2004), "Solving dynamic general equilibrium models using a second-order approximation to the policy function." Journal of Economic Dynamics and Control, 28, 755-775.

Schmitt-Grohé, Stephanie and Martin Uribe (2007), "Optimal simple and implementable monetary and fiscal rules." Journal of Monetary Economics, 54, 1702-1725.

Taylor, John B (1993), "Discretion versus policy rules in practice." Carnegie-Rochester Conference Series on Public Policy, 39, 195-214.

Walsh, James P (2011), Reconsidering the role of food prices in inflation. IMF Working Paper No. 11/71.

Wynne, Mark A (2008), "Core inflation: a review of some conceptual issues." Federal Reserve Bank of St. Louis Review, 90. 
Table 1: Share of Food Expenditure in Total Household Expenditure

\begin{tabular}{lc|lc}
\hline Developing Economies & Food Expenditure & Advanced Economies & Food Expenditure \\
\hline Indonesia & 53.0 & Japan & 14.7 \\
Vietnam & 49.8 & Germany & 11.5 \\
India & 48.8 & Australia & 10.8 \\
China & 36.7 & Canada & 9.3 \\
Russia & 33.2 & United Kingdom & 8.8 \\
Malaysia & 28.0 & USA & 5.7 \\
\hline Average & $\mathbf{4 1 . 6}$ & Average & $\mathbf{1 0 . 1}$ \\
\hline
\end{tabular}

Source: Household Surveys, CEIC, International Food Consumption Patterns Dataset, Economic Research Service, USDA and authors' calculations.

Notes: Data for developing economies are for 2005 while for advanced economies data are for 2006. Expenditure on food includes expenditure on food consumed at home only and does not include expenditure on beverages and tobacco. 
Table 2: Composite Measure of Access to Financial Services in Developing Countries

\begin{tabular}{lc|lc}
\hline Selected Countries & Percent with Access & Selected Countries & Percent with Access \\
\hline Argentina & 33 & Nigeria & 30 \\
Brazil & 56 & Philippines & 27 \\
Chile & 42 & Poland & 70 \\
China & 64 & Russia & 48 \\
India & 35 & South Africa & 54 \\
Indonesia & 20 & Thailand & 73 \\
Kenya & 42 & Turkey & 58 \\
Malaysia & 66 & & \\
\hline Median (29 Developing Economies): $\mathbf{4 2}$ & Median (27 Advanced Economies): $\mathbf{9 6}$ \\
\hline
\end{tabular}

Source: Global Findex Database, World Bank, 2011.

Notes: The composite indicator measures the percentage of the adult population with access to an account with a financial intermediary. The table only shows data for a selected group of individual developing countries. Reported medians are based on a larger sample of developing and advanced economies available in the database. 
Table 3: Parameter Values

\begin{tabular}{|c|c|c|}
\hline Paramet & Definition & Value \\
\hline \multicolumn{3}{|c|}{ Structural } \\
\hline$\lambda$ & Share of households in the food sector (who are credit-constrained) & 0.4 \\
\hline$\eta$ & Elasticity of substitution between food and nonfood & 0.6 \\
\hline$C^{*}$ & Subsistence level of food consumption given subsistence ratio of $1 / 3$ & 0.042 \\
\hline$\gamma$ & Non-subsistence food consumption share & 0.326 \\
\hline \multicolumn{3}{|c|}{ General } \\
\hline$\beta$ & Discount factor & 0.99 \\
\hline$\sigma$ & Risk aversion coefficient & 2 \\
\hline$\theta$ & Elasticity of substitution between different varieties & 11 \\
\hline$\psi$ & Inverse of Frisch elasticity of labor supply & 3 \\
\hline$\psi_{b}$ & Interest rate elasticity of debt (for technical reasons only) & 0.0007 \\
\hline$\alpha$ & Probability of not being able to reset price in each quarter & 0.66 \\
\hline$\xi$ & Elasticity of substitution between domestic and foreign goods & 0.7 \\
\hline$\zeta$ & Share of imports in total nonfood consumption & 0.3 \\
\hline \multicolumn{3}{|l|}{ Policy } \\
\hline$\rho$ & Degree of interest rate smoothing & 0.7 \\
\hline$\phi_{\pi}$ & Degree of response to inflation & 2 \\
\hline$\phi_{y}$ & Degree of response to output gap & 0.5 \\
\hline \multicolumn{3}{|l|}{ Shocks } \\
\hline$\rho_{a}^{f}, \sigma_{a}^{f}$ & Productivity shocks in the food sector: persistence, std. dev. & $0.25,0.030$ \\
\hline$\rho_{a}^{s}, \sigma_{a}^{s}$ & Productivity shocks in the sticky price sector: persistence, std. dev. & $0.90,0.020$ \\
\hline$\rho_{s}, \sigma_{s}$ & Terms of trade shocks in the export sector: persistence, std. dev. & $0.77,0.013$ \\
\hline$\rho_{\tau}, \sigma_{\tau}$ & Markup shocks in the sticky price sector: persistence, std. dev. & $0.90,0.010$ \\
\hline
\end{tabular}


Table 4: Welfare Comparisons Under Different Inflation Targets

\begin{tabular}{lcccccc}
\hline \multirow{2}{*}{$\begin{array}{l}\text { Financial } \\
\text { Markets }\end{array}$} & \multicolumn{2}{c}{ Welfare Gain } & & \multicolumn{2}{c}{ Weights in the Optimal Price Index } \\
\cline { 2 - 3 } \cline { 6 - 7 } Complete & Headline & Optimal & & Food Prices & Sticky Prices & Import Prices \\
\hline Incomplete & $-0.09 \%$ & $0.00 \%$ & & 0.00 & 0.00 & 0.00 \\
\hline
\end{tabular}

Notes: The optimal price index consists of food prices, sticky nonfood domestic goods prices, and import prices. Welfare gains under alternative inflation targets are derived as permanent consumption gains relative to strict core inflation targeting. 
Table 5: Welfare Comparisons Between Strict and Flexible Inflation Targeting

\begin{tabular}{|c|c|c|c|c|c|c|}
\hline \multirow{2}{*}{$\begin{array}{l}\text { Benchmark } \\
\text { Target }\end{array}$} & \multirow{2}{*}{$\begin{array}{l}\text { Alternative } \\
\text { Target }\end{array}$} & \multicolumn{2}{|c|}{ Welfare Gain } & \multicolumn{3}{|c|}{ Weights in the Optimal Price Index } \\
\hline & & Headline & Optimal & Food Prices & Sticky Prices & Import Prices \\
\hline Strict Core & Strict & $0.16 \%$ & $0.20 \%$ & 0.35 & 0.65 & 0.00 \\
\hline Flexible Core & Flexible & $0.12 \%$ & $0.17 \%$ & 0.34 & 0.66 & 0.00 \\
\hline Strict Core & Flexible & $0.07 \%$ & $0.11 \%$ & 0.34 & 0.66 & 0.00 \\
\hline
\end{tabular}

Notes: The optimal price index consists of food prices, sticky nonfood domestic goods prices, and import prices. Welfare gains under alternative inflation targets are derived as permanent consumption gains relative to the respective benchmark target. Strict inflation targeting refers to the monetary policy rule that only responds to inflation changes while flexible inflation targeting allows for responses to output fluctuations. 
Table 6: Sensitivity Tests

\begin{tabular}{|c|c|c|c|c|c|}
\hline \multirow{2}{*}{$\begin{array}{c}\text { Parameter } \\
\text { Value }\end{array}$} & \multicolumn{2}{|c|}{ Welfare Gain } & \multicolumn{3}{|c|}{ Weights in the Optimal Price Index } \\
\hline & Headline & Optimal & Food Prices & Sticky Prices & Import Prices \\
\hline \multicolumn{6}{|c|}{ A. Share of Rural Households (baseline $=0.4$ ) } \\
\hline 0.3 & $0.36 \%$ & $0.49 \%$ & 0.87 & 0.13 & 0.00 \\
\hline 0.4 & $0.16 \%$ & $0.20 \%$ & 0.35 & 0.65 & 0.00 \\
\hline 0.5 & $-0.02 \%$ & $0.09 \%$ & 0.22 & 0.78 & 0.00 \\
\hline 0.6 & $-0.15 \%$ & $0.04 \%$ & 0.14 & 0.86 & 0.00 \\
\hline \multicolumn{6}{|c|}{ B. Subsistence Ratio of Food (baseline $=0.33$ ) } \\
\hline 0.0 & $-0.07 \%$ & $0.00 \%$ & 0.08 & 0.92 & 0.00 \\
\hline 0.1 & $-0.06 \%$ & $0.01 \%$ & 0.14 & 0.86 & 0.00 \\
\hline 0.2 & $-0.03 \%$ & $0.03 \%$ & 0.21 & 0.79 & 0.00 \\
\hline 0.3 & $0.08 \%$ & $0.12 \%$ & 0.31 & 0.69 & 0.00 \\
\hline 0.4 & $0.56 \%$ & $0.63 \%$ & 0.48 & 0.52 & 0.00 \\
\hline \multicolumn{6}{|c|}{ C. Price Stickiness (baseline $=0.66$ ) } \\
\hline 0.5 & $0.13 \%$ & $0.16 \%$ & 0.42 & 0.58 & 0.00 \\
\hline 0.6 & $0.16 \%$ & $0.19 \%$ & 0.39 & 0.61 & 0.00 \\
\hline 0.7 & $0.14 \%$ & $0.19 \%$ & 0.32 & 0.68 & 0.00 \\
\hline 0.8 & $0.01 \%$ & $0.11 \%$ & 0.20 & 0.80 & 0.00 \\
\hline
\end{tabular}

Notes: The optimal price index consists of food prices, sticky nonfood domestic goods prices, and import prices. Welfare gains under different parameter values are derived as permanent consumption gains relative to strict core inflation targeting. 
Figure 1: Impulse Responses to a Negative Food Productivity Shock (Complete Markets)
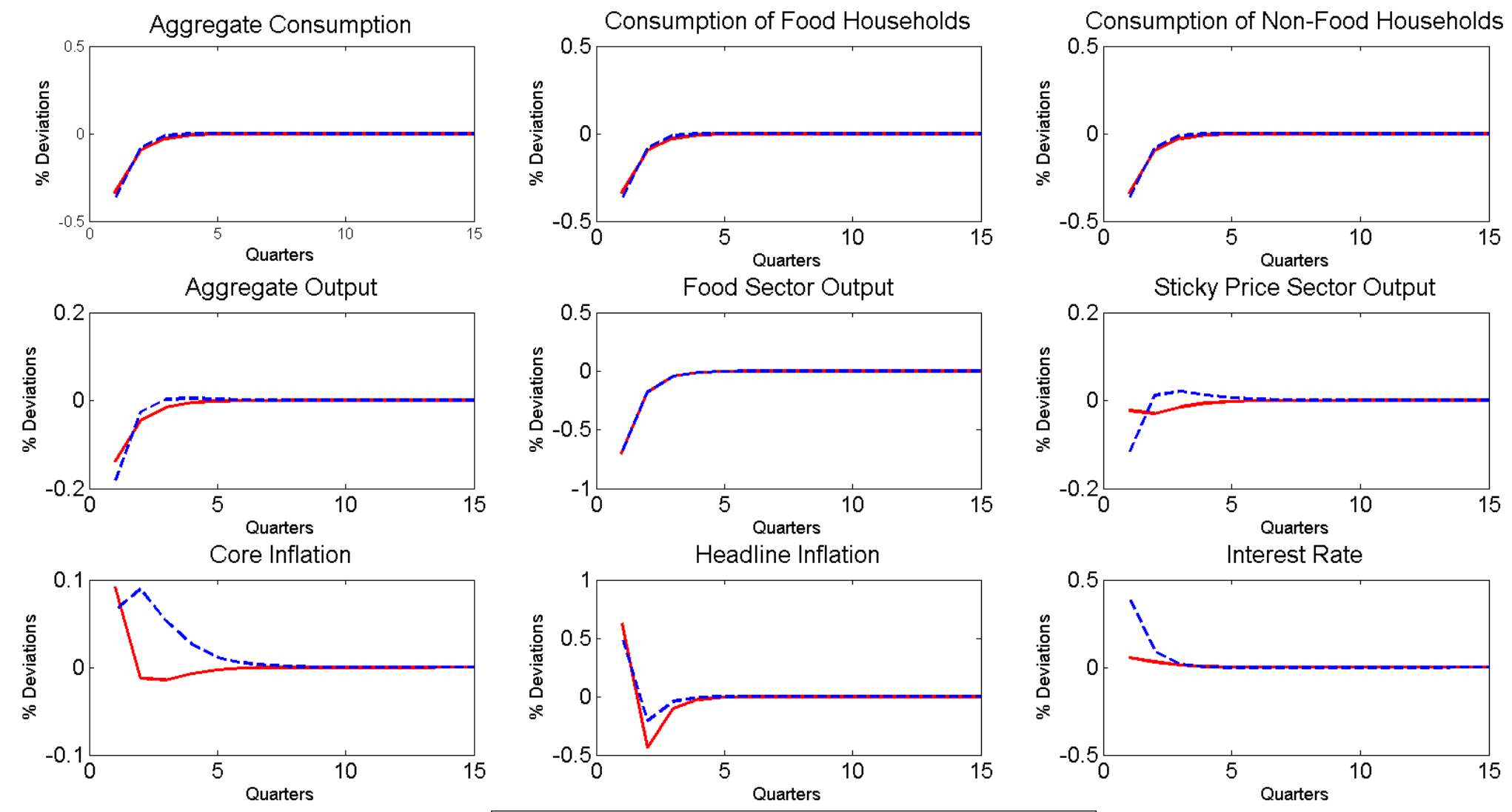

Core Inflation Targeting ---- Headline Inflation Targeting

Notes: The impulse responses shown above are to a one percent negative shock to food productivity. Each variable's response is expressed as the percentage deviation from its steady state level. 
Figure 2: Impulse Responses to a Negative Food Productivity Shock (Incomplete Markets)
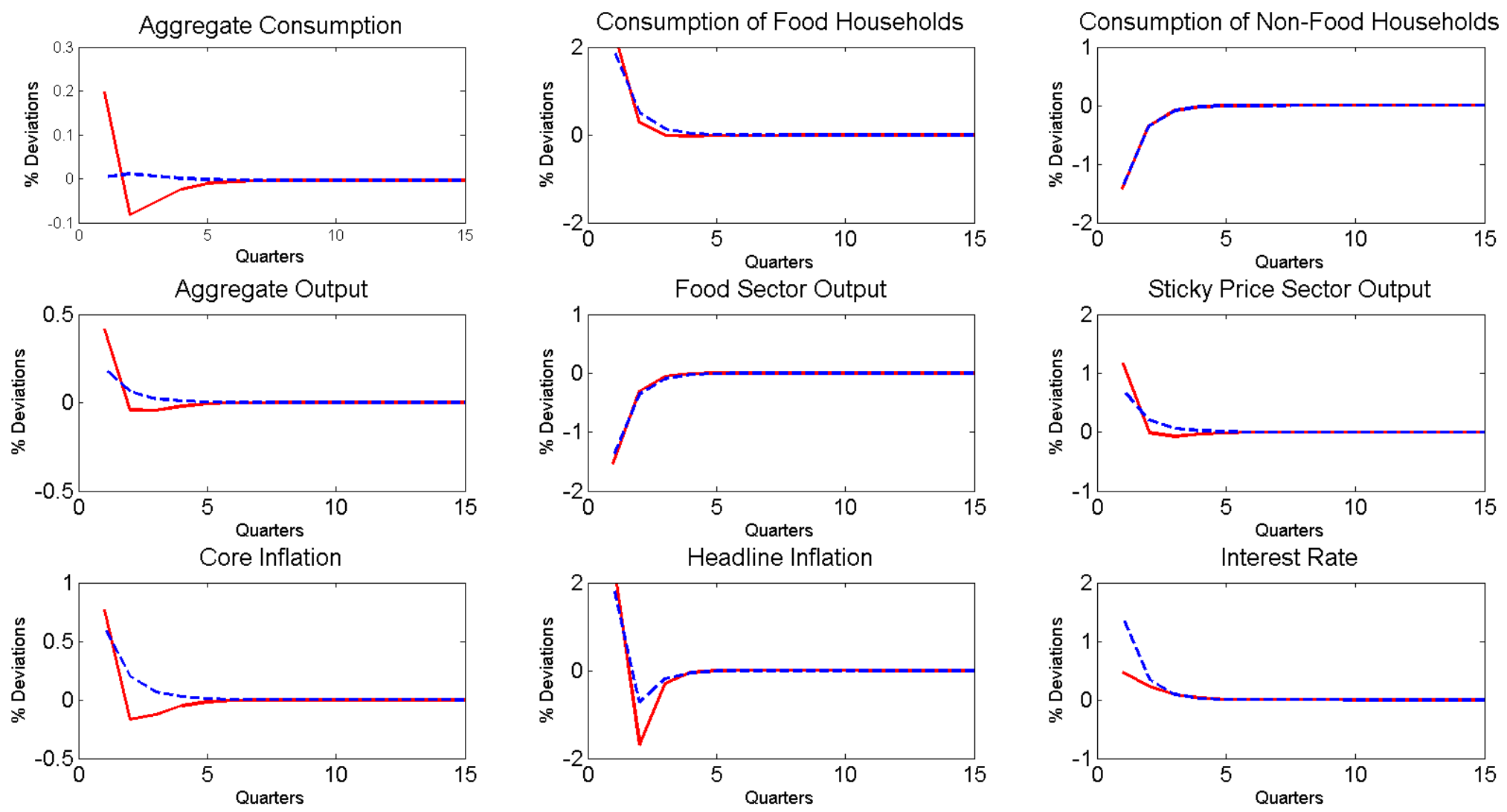

Core Inflation Targeting ---- Headline Inflation Targeting

Notes: The impulse responses shown above are to a one percent negative shock to food productivity. Each variable's response is expressed as the percentage deviation from its steady state level. 